\title{
The Effects of the Hydrogen Peroxide Colloidal-Ag on Dental Unit Waterlines and Waste Waters
}

\author{
Resmiye E. Tirali ${ }^{*}$, Gülçin Akça $^{2}$ and Omer E. Bulut ${ }^{3}$ \\ ${ }^{1}$ Baskent University, Faculty of Dentistry, Department of Pediatric Dentistry, Ankara, Turkey \\ ${ }^{2}$ Gazi University, Faculty of Dentistry, Department of Oral Microbiology, Ankara, Turkey \\ ${ }^{3}$ Baskent University, Faculty of Dentistry, Department of Oral and Maxillofacial Surgery, Ankara, Turkey
}

Received: November 29, 2015; Accepted: January 13, 2016; Published: January 23, 2016

*Corresponding author: Resmiye Ebru Tirali, Baskent University Faculty of Dentistry, Department of Pediatric Dentistry, 11. Sok. No:26 Bahcelievler, 06490 Ankara, Turkey, Fax: +009-0312-215 2962; E-mail: ebru_aktepe@hotmail.com

\begin{abstract}
The purpose of this study was to investigate the effect of a system which automatically adjusts hydrogen peroxide colloidal-Ag dose to reduce colonization and growth of heterotrophic bacteria in dental unit waterlines and wastewaters. Thirty dental units were assigned into three groups with respect to the protocol employed: Group 1 : 10 units were selected for automatic administration. Group $2: 10$ units were selected for manual administration and Group 3: 10 units served as controls. Water samples from DUWLs and waste waters were collected every week for ten weeks. They were inoculated onto various specific agar media and incubated at $28-37^{\circ} \mathrm{C}$ for $2-7$ days. After counting the colonies of microorganisms, the mean numbers were determined as cfu/mL A statistically significant difference in median total viable counts reduction was found for both treatment and control groups' dental units waterlines for all weeks $(p<0.01)$ However, there was no significant difference among the waste water samples. The tested system of has been found to be as effective as manual application for improving the dental unit waterlines. Yet, none of these systems has proved enough antibacterial effect for dental unit wastewaters.
\end{abstract}

Keywords: Hydrogen peroxide colloidal-Ag; Dental unit wastewater; Biofilm

\section{Introduction}

The issue of presence of large numbers of microorganisms in dental unit water has become a major concern in terms of increased risk of infection for dental patients and staff, and is incompatible with good hygiene and cross-infection control practices $[1,2]$. The bacteria isolated from Dental Units Waterlines (DUWLs) included both opportunistic ones and the pathogens [3]. The surfaces of DUWLs provide an ideal environment for developing of microbial biofilms [4]. Biofilms are well-organized communities of cooperating microorganisms that can include bacteria, protozoa, diatoms, and fungi [5-8]. These microbiotas are predominantly harmless, but potentially pathogenic organisms may also be present in the biofilm [9].

The high-speed dental instruments that are used during dental treatments produce bioaerosols composed of particles varying in size. Some particles evaporate forming droplet nuclei $<5 \mu \mathrm{m}$ in diameter that remain airborne for many hours [10]. This DUW contamination poses risks for immune compromised individuals [1]. In addition, chronic endotoxin inhalation represents an occupational respiratory hazard to dental professionals [11]. Furthermore, water line and hand piece anti-retraction valves can transport the pathogens from asymptomatic patients and cause cross-infection [12].

In addition to these concerns the issue of microbiological and chemical compounds in wastewater has become a major problem in terms of both human health and the environment. This situation led to the launch of studies for the examination of compounds in dental unit wastewater. To date, many techniques and antimicrobial agents were used to eliminate biofilm from the inner surface of DUWLs [13-15]. These techniques include the use of waterline flushing, independent water reservoir systems, distilled water, ultraviolet light, ultrasonic, drying of DUWLs, inline micropore filtration and periodic or continuous chemical disinfection [2,18-20].

The present study was investigated the ability of minimize biofilm formation of two different application method of hydrogen peroxide-based disinfectant in waterlines and wastewaters of dental units.

\section{Methods}

\section{Modifications of DUWLs}

This study was performed on dental units at Baskent University, Faculty of Dentistry, Department of Pediatric Dentistry. Thirty dental units which previously used municipal water system and never received any disinfectant in waterlines were selected. The municipal water system was shut down and in-built bottle system of dental units was utilized. In this way, distilled water can be used by filling the bottles of the dental units' water system.

Group 1: For the first group $(\mathrm{n}=10)$ dental units were modified to facilitate the addition of a disinfectant to the water used in the DUWLs by fitting an externally mounted purge system (Dose up, Ultrasan Elektronik Ltd. Ști. Ankara, Turkey). Using this 
system, the municipal water supply could be bypassed and the system used to add a disinfectant automatically and continuously to the DUWLs throughout patient treatment sessions. For this study continuous application of $5 \%$ hydrogen peroxide ColloidalAg (5\% Huwa-San Dent-6, Roam chemie, Belgium) was preferred and were applied to the DUWLs.

Group 2: For the second treatment group ( $\mathrm{n}=10$ ) $5 \%$ hydrogen peroxide Colloidal-Ag was applied manually to the water bottles of the dental units.

Group 3: 10 of the units served as controls and no disinfectant applied and only distilled water is used in bottles.

\section{Sampling of DUWLs}

For all groups; the water samples were taken from DUWLs every week for ten weeks period. After 30 seconds of flushing, samples were collected at approximately mid-morning from the distal outlets of the three-in-one syringes of DUWLs. Approximately $50 \mathrm{ml}$ of water sample passed through a sterile nozzle into a sterile water bottle containing $0.1 \mathrm{~g}$ sodium thiosulfate to remove any residual disinfectant. For Group 1 and 3 waste water samples were collected from a reservoir designed for the collection of waste water. Samples were returned to the laboratory in a cool box with in $1 \mathrm{~h}$ and then they were serially diluted, spread-plated in duplicate onto R2A agar plates (Merck, Darmstadt, Germany) and incubated at $28^{\circ} \mathrm{C}$ for seven days and average bacterial counts were expressed as colony-formatting units per milliliter (cfu/ mL). Total viable counts (TVCs) were used as the definitive measure of total microbial contamination of the water passing through the DUWLs. This was compared with the U.S. guideline for DUWLs of $\leq 200 \mathrm{cfu} / \mathrm{mL}$ as recommended by the ADA. They were inoculated onto various specific agar media and incubated at $28-37^{\circ} \mathrm{C}$ for $2-7$ days. After counting the colonies of microorganisms, they were identified and the mean numbers were determined as $\mathrm{cfu} / \mathrm{mL}$.

The presence of staphylococci was identified by culturing samples on mannitol salt agar for discrimination of S. aureus and they were also investigated by conventional microbiological test method and identified by API Staph system (BioMèrieux, France). The presence of Streptococci w was identified by morphologically and serologically by grouping specifies of them.

The presence of gram negative bacteria $\mathrm{w}$ was evaluated by using Citrate, Indole and urea media. Pseudomonadaceae were identified by culturing samples on Cetrimide agar media and using Triple sugar iron media and oxidase test. Besides, colonies which are supposed to be Pseudomonas aeruginosa were underwent biochemical identification test using API $20 \mathrm{NE}$ system (BioMèrieux, France).

The presence of Candida strains were evaluated by culturing them on Sabouraud Dextrose Agar dimorphically and were identified as yeast-like fungi by their morphological properties and by using germ tube assay they were defined as $C$. albicans and C. non albicans. Legionella spp. was evaluated by culturing the samples on Legionella selective medium.

\section{Statistical Analysis}

Data analysis was performed by using SPSS for Windows, version 11.5 (SPSS Inc., Chicago, IL, United States). Data were shown as mean \pm standard deviation (min-max).

The mean differences among groups within each measurement time were evaluated by One-Way ANOVA. When the $\mathrm{p}$ value from One-Way ANOVA are statistically significant post hoc Tukey HSD test was used to identify which group differ from others. According to the Bonferroni Correction, $p<0.005$ was considered statistically significant. The mean differences among measurement times within each group were analyzed by Repeated Measurement of ANOVA, Wilks' Lambda test. According to the Bonferroni Correction, $p<0.01$ was considered statistically significant. Logarithmic transformation was done for number of microorganism within each statistical analysis. For all possible multiple comparisons, the Bonferroni Correction was applied for controlling Type I error.

\section{Results}

Each sample was evaluated by culturing them on their specific agar media which are mentioned at methods. Then, total heterotrophic plate counts were calculated. The isolated and identified microorganisms were given at Table 1. Legionella strains weren't found in the samples.

Ten weeks of logarithmic mean of microorganism calculated for the whole groups (Figure 1). There was no significant difference between the treatment groups' DUWLs and had counts of less than $200 \mathrm{CFU} / \mathrm{mL}$ A statistically significant difference in median TVCs reduction was found between the treatment and control groups' DUWLs for all weeks $(p<0.01)$. However, there was no significant difference between Group 1 and control group's waste waters. Biofilm formation was more evident in the control group's both DUWLs and waste waters.

\section{Discussion}

The goal of infection control of DUWLs water is to minimize the risk from exposure to potential pathogens and to create a safe working environment for patients as well as dentists. Water used for cooling the hand pieces and flushing is considered as a way of microbiological transmission of pathogens to patients and doctors, and of cross-infections [19]. American Dental Association (ADA) states that 200 colony-forming units per milliliter (CFU/ $\mathrm{mL}$ ) as a standard microbial count for water samples [6,20]. For these reasons; effective mechanical techniques and chemical disinfectants for eliminating the biofilm from the inner surface of DUWLs need to be applied. Numerous suggestions for reducing the bacterial density in dental unit water have been proposed but none has been universally adopted that is both efficient at eliminating biofilm, as well as being safe for patients [16,21].

Biofilms have a big role in certain infectious diseases and importance in a variety of device-related infections so it is important to understand biofilm processes, effective control strategies to resulting improvement in patient management [7]. In a series of trials, treating of DUWLs with sodium hypochlorite, 
Table 1: Types of the microorganisms which are mostly isolated and identified from the samples.

\begin{tabular}{|c|c|c|c|c|}
\hline \multicolumn{2}{|c|}{ Sample groups } & Gram positive bacteria & Gram negative bacteria & Fungal agents \\
\hline \multirow[b]{2}{*}{ Group 1} & $\begin{array}{l}\text { Waterlines } \\
\text { samples }\end{array}$ & $\begin{array}{c}\text { Coagulase-Negative Staphylococci [CNS] } \\
\text { Streptococci spp. }\end{array}$ & - & - \\
\hline & $\begin{array}{l}\text { Waste water } \\
\text { samples }\end{array}$ & $\begin{array}{c}\text { Staphylococcus aureus Streptococci spp. } \\
\text { Viridans streptococci }\end{array}$ & $\begin{array}{c}\text { Pseudomonas aeruginosa, } \\
\text { Escherichia coli, Klebsiella sp. } \\
\text { Enterobacter spp. Citrobacter spp. }\end{array}$ & $\begin{array}{l}\text { Candida albicans, } \\
\text { Candida non albicans }\end{array}$ \\
\hline \multirow[b]{2}{*}{ Group 2} & $\begin{array}{l}\text { Waterlines } \\
\text { samples }\end{array}$ & $\begin{array}{c}\text { Coagulase negative staphylococci [ CNS], } \\
\text { Methicillin-Sensitive } S \text {. aureus [MSSA] }\end{array}$ & - & - \\
\hline & $\begin{array}{l}\text { Waste water } \\
\text { samples }\end{array}$ & $\begin{array}{l}\text { Coagulase-Negative Staphylococci } \\
\text { [CNS], Methicillin sensitive } \text { S. aureus } \\
\text { [MSSA], Streptococci spp. } \\
\text { Viridans streptococci }\end{array}$ & $\begin{array}{l}\text { Pseudomonas aeruginosa, } \\
\text { Escherichia coli, } \\
\text { Klebsiella spp. Enterobacter spp. }\end{array}$ & $\begin{array}{l}\text { Candida albicans, } \\
\text { Candida non albicans }\end{array}$ \\
\hline
\end{tabular}

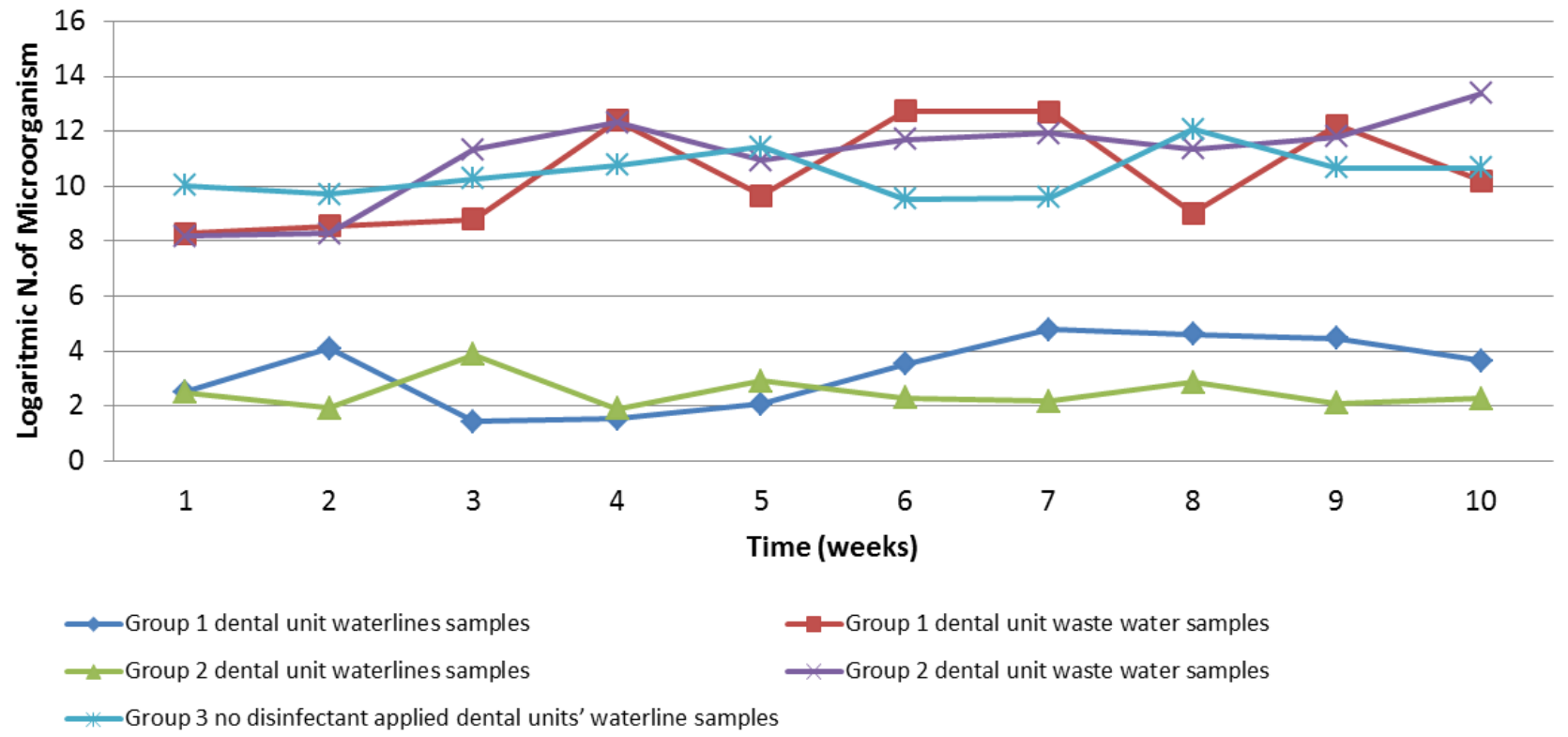

Figure 1: 10 weeks of logarithmic means of microorganisms.

glutaraldehyde, and isopropanol was investigated. These agents reduced microorganisms in effluent water but did not destroy the biofilm matrix in the DUWLs, even with periodic treatments [8]. Similar results were obtained for Listerine, Bio 2000, Rembrandt, and Sodium fluoride [18]. There are now an increasing number of commercial disinfectants that claim to reduce the microbial burden of the DUWLs and thereby minimize the risk of occupational exposure and cross-infection. A number of studies have evaluated a broad range of products, suitable for use in DUWLs, which are claimed to reduce the microbial loading of dental unit water systems and to remove the biofilm attached to the inner surfaces of the dental unit water line tubing [13-15,22]. The studies that investigated the effect of hydrogen peroxide silver ions disinfectant have shown that it is easy to use its continuous application caused a significant decrease in the number of total fungi. In addition, $91 \%$ of the treated water samples had a TVC of $\leq 200 \mathrm{CFU} / \mathrm{mL}$ after its application $[13,17,23]$. In this study; hydrogen peroxide Colloidal-Ag was used to reduce total viable counts in DUWLs and similar results were shown. In the present study, in the end of week 10, dental units' microbial counts which were treated with hydrogen peroxide colloidal-Ag, were less than $200 \mathrm{CFU} / \mathrm{mL}$ for both manual and automatic application. The effectiveness of the manual application of hydrogen peroxide Colloidal-Ag in the eradication of biofilm was shown in a previous study [24]. In the present study, automatic application system was found to be as effective as the manual application. Thus, a re-examination of the effect on wastewater was not needed. Although the manual application is as effective as the automatic application, problems can arise in applying the disinfectant according to the manufacturer's instructions as non automated procedures depends on the dental staff. So, it is important to know adjustment been done automatically.

In fact, in most countries, no distinction is usually made between the dental unit wastewaters and urban effluent, and this can cause potentially hazardous loads which are generally discharged directly into the public sewage network. Identifying environmental reservoirs of Methicillin-sensitive Staphylococcus aureus (MSSA), as well as Methicillin-resistant Staphylococcus aureus (MRSA) in the community, might be critical for controlling 
the spread of community-acquired staphylococcal infections [25]. Dental unit waterlines are known as reservoirs since they are frequently contaminated by pathogenic and opportunistic microorganisms and [26], the contamination of dental unit waterlines by MSSA strains is also important as MRSA strains because they are accepted as being a causative agent for the community- acquired infections and recently, the incidence of these types of infection are getting very much higher. In the present study, we have demonstrated MSSA strains in the waste water samples. Attention should be paid to the occurrence of MSSA since it is a probable way of contamination for people who are in contact with reclaimed wastewater. Previous studies investigated the effect of detergents, organic compounds, disinfectants and several metals for the hospital environment $[27,28]$. However, there scarcity of data on the topic of dental unit wastes waters' microbiological compounds and counts. One of the aims of this study was to investigate the effect of hydrogen peroxide Colloidal-Ag on dental unit waste waters. According to the results of this study; the tested dose of hydrogen peroxide Colloidal-Ag was ineffective to reduce TVC for the dental units waste waters. There are still areas that require further work in terms of controlling the microbial loading of dental unit waste waters such as engineering systems that can apply more efficient doses of disinfectants for the dental unit wastewater.

\section{Acknowledgements}

The present study has been accepted for oral presentation at FDI 2013 Annual World Dental Congress, Istanbul.

\section{Conflicts of Interest}

The authors declared any potential conflict of interest is disclosed.

\section{Key Points}

1. Hydrogen peroxide Colloidal- Ag disinfectant is effective in decontamination of DUWLs.

2. The system of automatic adjusting is effective as manual application of the material for improving the dental unit waterlines.

3. None of these systems has not proved enough antibacterial effect for dental unit wastewaters that has become a major problem in terms of both human health and the environment.

\section{References}

1. Pankhurst CL, Johnson NW, Woods RG. Microbial contamination of dental unit waterlines: the scientific argument. Int Dent J. 1998;48(4):359-68.

2. Shearer BG. Biofilm and the dental office. J Am Dent Assoc. 1996;127(2):181-9.

3. Barbeau J, Tanguay R, Faucher E, Avezard C, Trudel L, Côté L, et al Multiparametric analysis of waterline contamination in dental units. Appl Environ Microbiol. 1996;62(11):3954-9.

4. Singh R, Stine OC, Smith DL, Spitznagel JK Jr, Labib ME, Williams HN. Microbial diversity of biofilms in dental unit water systems. Appl Environ Microbiol. 2003;69(6):3412-20.
5. Barbeau J, Avezard C, Faucher E, Zalzal S, Prevost AP. Biofilms in dental unit waterlines: Ultrastructural and cytochemical analysis. Cell Materials. 1997;7(2):135-46.

6. Syzmanska J. Biofilm and dental unit waterlines. Ann Agric Environ Med. 2003;10(2):151-7.

7. Donlan RM. Biofilms: Microbial life on surfaces. Emerg Infect Dis. 2002;8(9):881-90.

8. Meiller TF, Depaola LG, Kelley JI, Baqui AA, Turng BF, Falkler WA. Dental unit waterlines: Biofilms, disinfection and recurrence. J Am Dent Assoc. 1999;130(1):65-72.

9. Forde A, O’Reilly P, Fitzgerald G, O'Mullane D, Burke FM, O’Sullivan M. Microbial contamination of dental unit water systems. J Ir Dent Assoc. 2005;51(3):115-8.

10. Szymanska J. Exposure to bacterial endotoxin during conservative dental treatment. Ann Agric Environ Med. 2005;12(1):137-9.

11. Huntington MK, Williams JF, Mackenzie CD. Endotoxin contamination in the dental surgery. J Med Microbiol. 2007;56(Pt 9):1230-4.

12. Walker JT, Bradshaw DJ, Bennett AM, Fulford MR, Martin MV, Marsh PD. Microbial biofilm formation and contamination of dental-unit water systems in general dental practice. Appl Environ Microbiol. 2000;66(8):3363-7.

13. Schel AJ, Marsh PD, Bradshaw DJ, Finney M, Fulford MR, Frandsen E, et al. Comparison of the efficacies of disinfectants to control microbial contamination in dental unit water systems in general dental practices across the European Union. Appl Environ Microbiol. 2006;72(2):1380-7

14. Shepherd PA, Shojaei MA, Eleazer PD, Van Stewart A, Staat RH. Clearance of biofilms from dental unit waterlines through the use of hydroperoxide ion-phase transfer catalysts. Quintessence Int. 2001;32(10):755-61.

15. Wirthlin MR, Marshall GW Jr, Rowland RW. Formation and decontamination of biofilms in dental unit waterlines. J Periodontol. 2003;74(11):1595-609.

16. Mills SE. The dental unit waterline controversy: defusing the myths, defining the solutions. J Am Dent Assoc. 2000;131(10):1427-41.

17. Linger JB, Molinari JA, Forbes WC, Farthing CF, Winget WJ. Evaluation of a hydrogen peroxide disinfectant for dental unit waterlines. J Am Dent Assoc. 2001;132(9):1287-91.

18. Fiehn NE, Larsen $T$. The effect of drying dental unit waterline biofilms on the bacterial load of dental unit water. Int Dent J. 2002;52(4):2514

19. Blake GC. Incidence and control of bacterial infection in dental spray reservoirs. Brit Dent J. 1963; 115(10):413-16.

20. Walker JT, Bradshaw DJ, Finney M, Fulford MR, Frandsen E, ØStergaard E, et al. Microbiological evaluation of dental unit water systems in general dental practice in Europe. Eur J Oral Sci. 2004;112(5):412-8.

21. Pankhurst CL, Philpott-Howard JN. The microbiological quality of water in dental chair units. J Hosp Infect. 1993;23(3):167-74.

22. Kettering JD, Muñoz-Viveros CA, Stephens JA, Naylor WP, Zhang W. Reducing bacterial counts in dental unit waterlines: Distilled water vs. antimicrobial agents. J Calif Dent Assoc. 2002;30(10):735-41.

23. Syzmanska J. Antifungal efficacy of hydrogen peroxide in dental unit waterline disinfection. Ann Agric Environ Med. 2006;13(2):313-7.

24. Meral ÖZALP, Ömer Engin BULUT, Atilla Stephan ATAÇ, Melike 
EKIZOĞLU, Didem KART, Hakan Hamdi ÇELIK, et al. The effect of hydrogen peroxide/colloidal silver on reducing the colonization and growth of heterotrophic bacteria in dental unit waterlines. Turk J Biol. 2013;37:336-341.

25. Sacchetti R, Baldissarri A, De Luca G, Lucca P, Stampi S, Zanetti F Microbial contamination in dental unit waterlines: comparison between Er:YAG laser and turbine lines. Ann Agric Environ Med. 2006;13(2):275-9.

26. Rosenberg Goldstein RE, Micallef SA, Gibbs SG, Davis JA, He X, George A, et al. Methicillin-resistant Staphylococcus aureus[ MRSA] detected at four U.S. wastewater treatment plants. Environ Health Perspect. 2012;120(11):1551-8. doi: 10.1289/ehp.1205436.
27. Emmanuel E, Perrodin Y, Keck G, Blanchard JM, Vermande P. Ecotoxicological risk assessment of hospital wastewater: a proposed framework for raw effluents discharging into urban sewer network. J Hazard Mater. 2005;117(1):1-11.

28. Boillot C, Bazin C, Tissot-Guerraz F, Droguet J, Perraud M, Cetre JC, et al. Daily physicochemical, microbiological and ecotoxicological fluctuations of a hospital effluent according to technical and care activities. Sci Total Environ. 2008;403(1-3):113-29. doi: 10.1016/j. scitotenv.2008.04.037. 